\title{
The concept of the Anthropocene as a game-changer: a new context for social innovation and transformations to sustainability
}

\author{
Per Olsson $^{1}$, Michele-Lee Moore $^{1,2}$, Frances R. Westley $^{3}$ and Daniel D. P. McCarthy ${ }^{3}$
}

\begin{abstract}
After tracing the antecedents of the concept and considering its intersection in social innovation research, we put forward the argument that the Anthropocene concept points to three areas of thought that are strategically imperative and must be accelerated if social innovation theory and practice is to prove transformative and respond to the challenges associated with the Anthropocene. First, we contend that the current debate on social innovation for sustainability lacks a deeper focus on human-environmental interactions and the related feedbacks, which will be necessary to understand and achieve large-scale change and transformations to global sustainability. Many innovations focus on only the social or the ecological, and we believe a more integrated approach will be needed moving forward. Second, social innovation research must confront the path-dependencies embedded within systems, and we propose that the act of "bricolage," which recombines existing elements in novel ways, will be essential, rather than single variable solutions, which currently dominate social innovation discussions. Finally, we put forward the idea that confronting the cross-scalar nature of the Anthropocene requires revisiting both the scope and temporal nature of social innovations that are most typically focused upon by scholars and funders alike. We believe the concept of the Anthropocene creates new opportunities for social innovation scholars to imagine new possibilities.
\end{abstract}

Key Words: Anthropocene; bricolage; scaling; social-ecological systems; social innovation; transformations to sustainability

\section{INTRODUCTION}

Throughout the world, substantive efforts have been invested in social innovations, that is, various initiatives such as policies, processes, programs, platforms, and practices that will, over time, transform the defining routines, resource and authority flows, or beliefs of the broader social system in which they are introduced (Westley and Antadze 2010). However, these social change initiatives are being undertaken in a world that is itself, rapidly changing. We draw attention to the concept of the Anthropocene and argue that, if taken seriously, it is a game changer for the field of social innovation practice and theory. Although social and technical innovation are often treated as our hope, that we can innovate our way out of the environmental crisis that is looming, unless those innovations are undertaken in ways that are different from the social innovations of the past, their impact is as likely to be negative as positive.

Beyond repeatedly demonstrating the negative impacts that humans have had on the Earth's environment, scholars have argued for several decades that humans have become the major driving force for global changes in the biophysical environment (Vernadsky 1945, Lovelock 1972, Crutzen and Stoermer 2000, Rockström et al. 2009). Although climate change and the alteration of atmospheric carbon concentrations are the most prominently recognized indicators of the human influence, Steffen et al. (2011) explain that other changes include the significant alteration of other biogeochemical cycles, the modification of the hydrological cycle through land use change, and the likelihood of driving a sixth major extinction event in Earth history (see also Steffen et al. 2005). The nature of humans' impact on the global biophysical system has become so dominant that scientists have proposed that the last 216 years of the existing Holocene period should become recognized as a new geological epoch, termed the Anthropocene (Crutzen and Stoermer 2000, Crutzen 2002, Steffen et al. 2011, Lewis and Maslin 2015).
As yet, the Anthropocene has not been given formal ratification by the International Union of Geological Sciences (IUGS) in the Geological Time Scale, but as a concept the Anthropocene is the most recent in a long line of neo-Malthusian/limits-to-growth conceptions of human-environment interactions. Steffen et al. (2011) provided readers with a comprehensive history of the conceptual antecedents. These antecedents include familiar reminders of limits such as NASA's "Earthrise" photography, the Club of Rome's 1972 report on Limits to Growth, as well as more direct references to the concept including a 1992 popular book about Global Warming that contained a prophetic, early reference to the concept of the Anthropocene: "perhaps earth scientists of the future will name the new post-Holocene period for its causative element - for us. We are entering an age that might someday be referred to as, say, the Anthrocene (sic)" (Steffen et al. 2011:843).

As with any new socially constructed framing of human activity, the concept has been contested (Malm and Hornborg 2014, Cook et al. 2015, Davison 2015, Lövbrand et al. 2015) for its sweeping generalizations about human impacts to Earth. Critics argue that the homogenizing discourse ignores the reality that such impacts have been mostly generated by those engaged in, and benefiting from, postindustrialized, neoliberal economies and consumption patterns, and yet, in the immediate term, the negative impacts described will most severely affect those who have not contributed or benefited from these dominant forces (Biermann 2014, Castree 2015, Cook et al. 2015).

Regardless of the final scientific decision about the epoch and the valid criticism about the construct itself, the concept of the Anthropocene is a powerful one, guiding our attention and our discourse to different phenomena and different actions (Galaz 2014, Brondizio et al. 2016). As such, we argue it is a game changer, with the potential to change the conversation around transformation and sustainability. Indeed, it is already doing so. 
Debates and analytical frameworks for considering how to secure a "good life" for people today and in the future have proliferated in recent literature, as are discussions about altering the unsustainable trajectory of human activity that earned the label Anthropocene in the first place (Rockström et al. 2009, Leach et al. 2013, Bennett et al. 2016). The concept has highlighted a growing sense of urgency; we need to better understand the processes of transformation and innovation and marry that knowledge with our growing understanding of complex socialecological interactions to build the capacity to both respond to new disturbances and risks and to move toward sustainable pathways.

In this paper we will explore the role that social innovations can play in supporting transformations to sustainability, transformations needed in light of the existing global environmental challenges and in the interest of moving away from the current unsustainable pathways that have contributed to the creation of the precarious situation referred to as the Anthropocene in the first place. The understanding of the dynamics of social innovation in general, and social-ecological innovation in particular (Olsson and Galaz 2012), is that growing and competing theories are proliferating (Howaldt and Kopp 2012). It is our contention in this paper that social innovation may play a critical role in achieving new pathways to sustainability, but we argue that such transformation may not keep pace with the extent and pace of change implied by the Anthropocene concept. We therefore question whether the current technological and social innovations and sustainability initiatives supposedly contributing to the large-scale transformations that humanity needs, are actually reinforcing current unsustainable pathways. In summary, we assert that the introduction of the Anthropocene concept presents an important opportunity to recalibrate the scholarship that examines such social change-making theories and the practices that such scholarship has generated.

\section{SOCIAL INNOVATION AS AN EMERGING FIELD}

The emerging emphasis on the importance of social innovation has resulted in a growing industry of social innovation experts, often referred to as "change makers," "social entrepreneurs," and "social innovators," or "system entrepreneurs," many of whom are seeking to have an impact at a large, albeit, not well-defined, scale (e.g., Mulgan et al. 2007, Murray et al. 2010, Pulford 2010, Schwab Foundation for Social Entrepreneurship 2013, Bria 2015, Deacon 2016). Moulaert et al. (2013) attribute this to both the analytical interest and the tendency for practitioners to overuse the term as a buzzword for a range of policies, often appropriating it.

However, it has stimulated the growth of a new area of scholarship, social innovation, which, although in its infancy is developing in theoretical sophistication (Nicholls and Murdock 2012, Cajaiba-Santana 2014, Moulaert et al. 2013, Nicholls et al. 2015). The scholarship draws on literature from work on innovation systems, resilience theory, entrepreneurship theory, organizational change literature, and others (Howaldt and Schwarz 2016). This emerging field attempts to understand how individuals, organizations, and networks may work to generate, select, and institutionalize novel solutions with specific social, and at times, environmental, goals, but it does so from numerous perspectives.
One stream of research that has engaged with the ideas of social innovation is the field of social entrepreneurship and social enterprise. Scholars in this field have sought to extend understandings of entrepreneurship that are focused on individuals and organizations creating novel solutions to social challenges (Mair and Marti 2009, Phills et al. 2008, Dacin et al. 2010), although not necessarily with an emphasis on whether or not the solutions they create have broad systemic impact. Progress has been made, within this approach, to (i) describe the diverse types of previous and existing "shared value" start-ups and organizational forms, such as hybridized business and nonprofit models around the world (Porter and Kramer 2011); (ii) to understand some of the tools used by social entrepreneurs to achieve success (e.g., Shaw and de Bruin 2013, Corner and Ho 2010); and, (iii) whether and how these can be adopted within, or create a challenge to, existing business, nonprofit, and for-profit frameworks (Phillips et al. 2015). However, few of these are specifically focused on social-ecological problem domains or explicitly on environmental sustainability, and those that do (e.g., Osburg and Schmidpeter 2013), are rarely focused on broad system transformation.

Another stream is represented by the work done by Mulgan (2006, et al. 2007) and others (Dees et al. 2004, Murray et al. 2010), which has mapped out a variety of strategies by which social innovations enter mainstream social institutions as well as how such innovations spread. This work is rich in detail and is highly practical, effectively bridging the worlds of public policy professionals, social sector practitioners, and philanthropists. However, this stream has not tended in the past to emphasize social innovations that are systemically transformative, nor has this body of work, focused its purpose on analyzing innovations with explicit consideration of global ecological dynamics relevant to the claims for a new Anthropocene era.

Another strand of social innovation research has developed frameworks suited for investigating a combination of grassroots movements (Seyfang and Smith 2007, Seyfang and Haxeltine 2012) and large socio-technical transitions that have occurred (Smith et al. 2005, Loorbach et al. 2016, Avelino and Wittmayer 2014). This scholarship draws heavily on a range of social theories to study the relationship among social and technological variables in transformative change processes, and how to move the lessons learned into practice, but it also explicitly engages with complex system dynamics and questions of long-term sustainability.

Perhaps most closely linked to the concept of the Anthropocene, system transformation, and linked social-ecological systems is the work associated with Westley et al. (2006, 2013, 2016). This work has been primarily founded on a complex systems and resilience approach and is focused squarely on the role of social innovation in transforming intractable problem domains, and on institutional or systems change (e.g. Westley et al. 2006, Westley 2013). This group, primarily although not exclusively linked to the Waterloo Institute for Social Innovation and Resilience, has sought to understand the role of policy in facilitating and generating social innovation (Moore et al. 2012a, Tjornbo and Westley 2012), networks (Moore and Westley 2011) and agency (Dorado 2005, Westley et al. 2013) in enabling the movement of innovations across scales, social finance (Antadze and Westley 2012, Geobey et al. 2012, Moore et al. 2012b) in supporting 
alternative pathways, and cultural shifts (Moore et al. 2015) or power changes (Moore and Tjornbo 2012, Moore et al. 2014) in creating room for social innovations to emerge and take hold. However, to date this work has also not explicitly engaged with the concept of the Anthropocene, and as in the case of the previous theories, the sense of urgency, the scale of the desired change and the normative challenges this presents has not been adequately addressed.

In sum, from reviewing the emerging strands of social innovation research, we believe that the challenge remains to address the inextricable link between social systems and ecosystems and to adopt a time frame for exploring change implied by the concept of the Anthropocene. Although some of the above work has emphasized the social-ecological links (Biggs et al. 2010, Walker and Westley 2011, Westley et al. 2011, Olsson and Galaz 2012) or has examined the temporal nature of social innovation throughout history (Mumford 2002, Mumford and Moertl 2003, McGowan and Westley 2015), this work needs further development to reach its potential. Therefore, we argue that conceiving the current geological epoch as the Anthropocene potentially represents a game-changer for social innovation research. We accept the definition of game-changers as as macrotrends that are perceived to change the rules of the game. that is, to change how society is organized and defined by today's understandings, values, institutions, and social relationships (Avelino et al. 2014).

\section{SOCIAL INNOVATION IN THE ANTHROPOCENE}

The Anthropocene concept highlights the double-edged sword presented by social innovation. The Anthropocene era, and particularly the period from the 1950s onward, has been deemed a significant period referred to as the "Great Acceleration" (Hibbard et al. 2007, Lewis and Maslin 2015, Steffen et al. 2015, Gaffney and Steffen 2017). During this period, the global population has doubled, and economic activity has exploded, which has been linked to substantial growth in a range of national industrial and household indicators, such as the use of chemical fertilizers, telephones, the number of fast food restaurants, total real GDP, foreign direct investment, along with infrastructure development such as the damming of rivers (Steffen et al. 2015).

Although the increases in these and other indicators contributed to improved human well-being in several regions in the world, largely favouring the Global North or the elite in the Global South, it also had a major influence on interlinked physical, chemical, and biological processes of the Earth system (Steffen et al. 2011). Therefore, coinciding with the social, technological, and economic change was a similar rapid growth in factors indicating environmental degradation, such as atmospheric carbon dioxide concentrations, coastal zone nitrogen flux, tropical rainforest and woodland loss, and biodiversity loss (Steffen et al. 2015). This has reduced ecosystem resilience and caused these systems to reach or cross critical thresholds and tipping points to more degraded states (Lenton et al. 2008, Rockström et al. 2009), which in turn is threatening human existence because of our dependence on functioning ecosystems. Therefore, human ingenuity and innovation capacity, whether social or social-ecological has driven the current unsustainable trajectory; it has in fact produced the conditions we call the Anthropocene (Westley et al. 2011). Consequently, the challenge that the Anthropocene concepts presents is to understand if, and how, we are to create a "good Anthropocene" (Ellis 2011) from a social innovation perspective. We claim that the gravity implied in such a discourse demands that social innovation scholars will need to grapple with three interlinked, strategic imperatives.

The first strategic imperative involves the need to expand our analysis of social innovations to include consideration of the dynamic nature of social-ecological system interactions. This perspective involves recognizing the urgency of action as the impacts associated with the Anthropocene begin to manifest in a many-fold transgression of planetary boundaries. The second strategic imperative directly relates to the notion that the concept of the Anthropocene is, and its implications are, inherently systemic and integrated. We draw on the concept of "pathdependence" from systems thinking that generally refers to the idea that there are a limited subset of possible outcomes that can be result based on the history of the system (e.g., Arthur 2009). Therefore, if the innovation proposed does not actively alter the path that underlies the Anthropocene, the innovation may end up reinforcing them. Thus, we use the concept of "bricolage," as a heuristic to ensure proposed innovations in the Anthropocene actively break from the path-dependence of the system. Social innovation scholars will need to develop methods of evaluating the degree to which innovations in fact contain, in their initial design or through a process of bricolage, the reconciliation of social and ecological elements. Even the most seemingly social challenges (gender inequity, for example) may shape, and are shaped by, changes in ecosystems, and thus, innovative programs in this domain should include elements that reflect that link. That is, social innovations must not just consider innovations that help us respond to the global environmental changes that are documented as part of the Anthropocene era, rather, innovations are needed that can move the global trajectory away from this trend, so that humans become a positive force in their relationship to ecological systems. Although the need for integration is widely recognized in the ecological and social sciences focused on sustainable development goals (Norström et al. 2014, Hajer et al. 2015), there has been little explicit integration of this thinking into social innovation research.

Finally, we argue that a third strategic imperative relates to the temporal urgency that the Anthropocene discourse highlights. Social innovation must be seen as a cross-scalar, strategic enterprise, with agents capable of accelerating the movement of an idea from invention to institutionalization, at a speed that thus far, appears unprecedented in previous paradigms of social transition or transformation. That is, if we take seriously the idea of the Anthropocene and the need to prevent the crossing of further tipping points or planetary boundaries (Steffen et al. 2015), social innovations will need to move through the entire innovation process faster than ever before. Whether this is possible remains to be seen, but at the very least, there is a need to integrate the concept of time more meaningfully into social innovation theory.

We explore the three interlinked, strategic imperatives for social innovation research in the Anthropocene. In doing so, we review how current social innovation efforts are falling short of confronting the factors that have contributed to the Anthropocene and therefore, falling short of confronting issues 
that may threaten the resilience of humans and numerous other species on Earth. If the theory and practice of social innovation ignores the game-changer posed by understanding the concept of the Anthropocene, it may quickly become irrelevant. Our discussion of current efforts is based less on the scholarly work reviewed above, which to date has largely been confined to theory development and limited case comparisons, but rather on the extensive surveys of social innovation initiatives conducted by philanthropic foundations and government sponsored think tanks, such as the Young Foundation, NESTA, EU Policy on Social Innovation, European Commission, Oxford Saiid School with Skoll Foundation, Schwab Foundation, and Ashoka Foundation, which support socially innovative initiatives in various regions of the world. Given our focus and purpose, we specifically narrowed our search to reports and reviews that included the terms "environmental" and/or "sustainability" as well as "social innovation" because these presumably have made the most explicit attempt to consider issues relevant to the Anthropocene argument. Our review included English language reports only and we recognize that limitation. Our selection also focused on reports published in the last decade to capture the most cutting-edge efforts.

\section{STRATEGIC IMPERATIVE \#1: CONFRONTING THE SOCIAL-ECOLOGICAL CHALLENGE}

Although some social innovation initiatives are explicit in their orientation toward environmental challenges (e.g., Murray et al. 2010, Skoll Foundation's 2015 environmental sustainability program), for the majority, innovation is frequently not connected to any ecological context at all. Instead, the sole focus and rationale for social innovation is upon improving social connectivity, cohesion, and inclusiveness and the ability for individuals to participate in the market. For example, the European Commission's program on social innovation includes numerous activities, one of which is the Social Innovation Competition that awards three winners each year with a financial prize and other support, such as training in the Commission's social innovation academy (see European Commission 2016). The past year's competition focused on refugees, and award winners focused on innovations such as a virtual reality platform that allowed users to understand the experience of being a refugee, and an educational and training program for furniture production, language, and additional job application support for refugees and migrants (European Commission 2016). Although these programs will ideally improve the socially isolating experience often associated with refugees specifically and migration more generally, they do not consider the broader socialecological system in which these challenges emerged, nor do they connect them with any consideration of the Anthropocene (see also Pulford Addarii 2010).

Research from disciplines outside of social innovation has demonstrated that when critical ecological thresholds are crossed, degradation in the social system can and often does follow (e.g., Homer-Dixon 1999, Kinzig et al. 2006, Cinner 2011). In addition, the social costs and benefits that follow from the activity that caused the degradation are not evenly distributed. The result is that the acknowledgement of social costs of ecological degradation are slowed if not suppressed altogether. For example, the social costs of environmental degradation caused by the extraction industries are more likely to be experienced by local and indigenous communities (see, for instance, Mascarenhas 2007, Booth and Skelton 2011, McCarthy et al. 2014), while the benefits are reaped by those who already possess economic and political power, but who often reside in other geographic regions (Carmin and Ageyman 2011). This inequality obscures an accurate coupling and the related estimation of the linked social and ecological costs and benefits. One example of this paradox involves the Green Revolution, which included the introduction of specific agricultural techniques, but was embedded in the broader industrial complex and global economic system (for a much fuller discussion, see Cleaver 1972, Freebairn 1995, Shiva 2016). In the short term, food insecurity was reduced for millions of people, but the approach caused longer term damage to the environment, and created social vulnerability for millions of other people because of volatility in the pricing mechanisms that shape the world's global food system (Godfray et al. 2010). Another example is that violent uprisings in countries where the environment has been degraded still come as a surprise (HomerDixon 1999).

Ultimately, we argue that the Anthropocene construct demands us to consider that any innovation has both a social and ecological element - that is, one cannot have a social innovation without an ecological impact, nor an ecologically-based innovation without considering the social impact (Olsson and Galaz 2012, Moore et al. 2014). Too many examples of addressing only one side of the equation continue to be promoted in the literature on social innovation, such as the prominence and accolades often given to the emergence of small-scale, collective action arrangements as successful social innovations (e.g., Mulgan et al. 2007). The challenge lies in their predominantly social (and often economic) focus. One widely studied case, profiled for its success, involves the Maine lobster fishery system, known for its sophisticated collective action and multilevel governance system, which has resulted in a sustained, regulated, economically valuable lobster fishery (Acheson 1988). Upon closer inspection, the Maine fishery seems to have followed the historical pattern of fishing-down food webs (Jackson et al. 2001) and has been linked to the depletion of the cod fishery, because the absence of cod enabled the expansion of species lower in the food web, such as lobsters. Lobster fisheries have become a type of coastal monoculture along the northeastern U.S. coastline, with the majority of the lobster population being artificially fed herring that is supplied as bait in lobster pots (Grabowski et al. 2010). The lobster has a high market price, which has helped to sustain the social organization and economic viability of the fishery. However, given the loss of functional diversity in the marine system, the socialecological system is now highly vulnerable to disturbances, such as lobster disease. If such a "surprise" occurs, the lobster population might be decimated over huge areas, perhaps triggering a shift into a very different social-ecological system in which coastal waters no longer provide a viable livelihood for local fishermen (Steneck et al. 2011). Given that lobster fishing is central to regional identity, and to other food-related livelihoods, the potential loss of lobster fishing could have severe detrimental social and cultural impacts that go beyond the obvious and immediate economic impacts.

Similarly, focusing only on the ecological or biological aspects as a basis for decision making for securing ecological integrity and promoting sustainable development may also lead to conclusions 
that are too narrow. A case in point is the establishment of the Maya UNESCO Biosphere Reserve in Guatemala (ManuelNavarrete et al. 2004). The goal was to preserve the remaining rainforest that coevolved with Mayan culture for centuries. The Guatemalan Congress established the reserve in 1990 according to strict biological criteria dictated by external experts and with little or no consideration of cultural and social implications. The response from local people and resource users was violent, and the establishment of the reserve resulted in a decade of struggle between conservationists and local people (Sundberg 2006). This, in turn, led to the development of more participatory conservation strategies, but the integrity of the Mayan forest remained at stake (Taylor 2010).

The Maine and Guatemala case studies illustrate that a focus on interconnected social and ecological systems is of crucial importance but is a difficult challenge. We assert that the tendency to focus on either the social or the ecological or the economic may have been reinforced by models such as the "triple bottom line" framework that gained prominence in support of the concept of sustainable development (Fig. 1). The discourse in social innovation is rife with language and references "to accelerate market innovation to meet social and environmental goals" (Murray et al. 2010:193). We argue that the Anthropocene construct indicates a need to re-envision the relationships among these elements, where the social and economic elements are viewed within the ecosystem (Fig. 2). Without it, some social innovation scholars continue to push market-based growth and "trade off" thinking that inevitably contributes to perpetuating the same negative social-ecological feedbacks and relationships (Folke et al. 2016).

Fig. 1. The social, environmental, and economic pillars often associated with sustainable development and "triple bottom line" thinking (a) has often led to trade-off decisions that either neglect the social-ecological, or strongly favor the economic (b). llustration: Jerker Lokrantz, Azote, for Stockholm Resilience Centre.
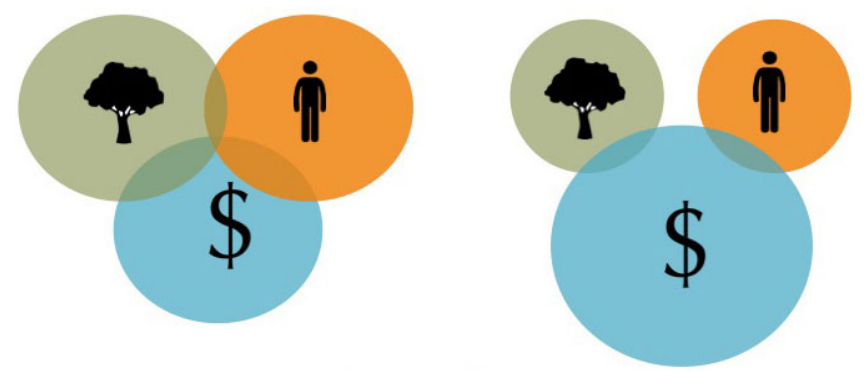

Ashoka Foundation's Full Economic Citizenship program may run such a risk, although this certainly is not an inevitable outcome. The Full Economic Citizenship program is aimed at ending the exclusion of two-thirds of the world's population from global markets and to ensure that every individual has the ability and choice to engage in local and global economies, specifying that this may be as "consumers, producers and creators of wealth" (Martinez 2010). The potential of this program to alter financial resource flows does create an important opportunity for system transformation, but only if this shift is accompanied with changes in authority, changes in norms, beliefs, and values and the way those are institutionalized in law, policy, and in financial products, and if this alters a set of social feedbacks with the surrounding ecosystems. Otherwise, simply supporting the growth of more producers and consumers will ignore the need to support a shift in how production and consumption could be developed to consider ecological feedbacks, so as not to repeat existing global patterns (Spaargaren and Mol 2008, Enfors 2013).

Fig. 2. Economic and social elements must be understood to be nested within ecosystems, not as separate elements to be traded off. llustration: Jerker Lokrantz, Azote, for Stockholm Resilience Centre.

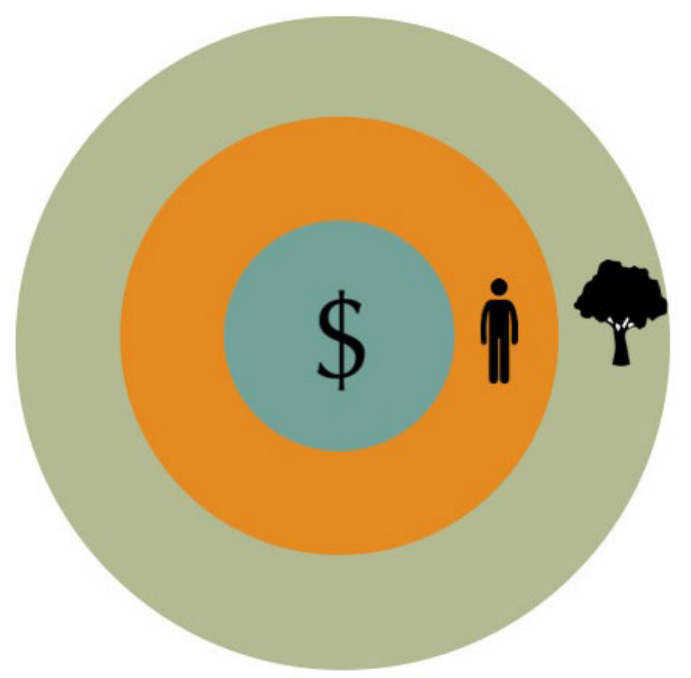

Last, the Anthropocene construct indicates that the current global trajectory must be altered significantly enough that humans will become a positive force on Earth. Many of the existing social innovations that have been documented in relation to the environment focus on simply reducing humans' footprint on the planet (e.g., Pulford 2010, Skoll Foundation 2015). For instance, Mulgan et al. (2007) describe how the reality of climate change requires that humans think about transportation, energy, housing, and urban design and development in new ways, all to reduce carbon emissions, while Murray et al. (2010) highlight a home insulation program in the UK as a social innovation. The Anthropocene construct would indicate this reduction of human impact is necessary, but it may be insufficient because questions remain about whether these same initiatives, such as insulating a home, have the potential to fundamentally rewire humanenvironmental relationships. Instead, the need exists to generate, adopt, and institutionalize innovations that build on a vision that humans can be a positive force on this planet (Bennett et al. 2016). For instance, ideas such as regenerative economies, integrated fish farms, and agricultural systems that create more nature when used would not only minimize impact, but would ensure humans are contributing to the restoration, renewal, and regeneration of the Earth's biosphere (Olsson and Galaz 2012).

To summarize, the Anthropocene concept is a game-changer for social innovation research in that it demands the social-ecological 
context be considered for any innovation. Current research and practice of social innovation is largely content to treat social innovations as if they have little or no relationship to ecological considerations. Because this separation of the social from the ecological is at the heart of the dynamic that has created the current unsustainable pathway, a broader, more persistently holistic definition of social innovation is required, despite the interdisciplinary challenges of doing so.

\section{STRATEGIC IMPERATIVE \#2 - CONFRONTING PATH- DEPENDENCE AND THE BRICOLAGE CHALLENGE}

The concept of "path-dependence" in systems thinking, in its basic form, refers to the fact that "history matters" and that there are a limited subset of possible next steps that can be taken based on the history of the system (Arthur 2009). In many ways, if we do not actively alter the path that underlies the Anthropocene, we will end up reinforcing it. We argue that by using the concept of bricolage, the path-dependence of the system can be altered and wholly new systemic opportunities opened up. Social innovation research based on complex systems thinking and resilience has found that innovative solutions that truly have a systemic impact are not just about a single invention or novelty (Westley et al. 2006, Goldstein et al. 2010, Moore et al. 2015). Instead, social innovations typically involve the recombination of pre-existing and new ideas, concepts or technologies to form something novel (Murray et al. 2010). This act of recombination has been termed bricolage, drawn from the junk collectors in France and defined as making creative and resourceful use of whatever materials are at hand, regardless of their original purpose (Westley 2013).

Westley (2013) outlines an illustrative example of bricolage using the case of Barefoot College, established originally in India. The Barefoot College concept is not a single idea; it combines work on education, gender empowerment, rural electrification, health, and more, all while challenging the conventions of village life, professional associations, and traditional culture, which in turn, are linked to institutions that are global in nature (Roy and Hartigan 2008). The initiative is rooted in a Ghandian tradition, with a focus on providing a platform for villagers to learn from each other to solve basic needs (Westley 2013, Barefoot College 2016). The approach of Barefoot College has combined training individuals in the use of nonfossil fuel energy technologies such as solar energy for heat and light, but it was initially done with a special emphasis on training grandmothers and building technical capacity in illiterate and uneducated communities while empowering women (and later youth), by connecting them with governance systems and using social entrepreneurship approaches (Barefoot College 2016). In this case, the individual elements themselves were not novel: solar energy is increasingly widespread, gender empowerment has long been a development priority, and social enterprise is frequently embraced in poverty alleviation programs. However, it was the juxtaposition of elements not normally combined that allowed Barefoot College to begin to address a cluster of intractable problems including gender inequalities, and health, education, and energy needs of rural villages in the India and later, other countries (Westley 2013).

We would argue that not only does the concept of bricolage help to illuminate the multifaceted nature of successful innovation, but that the concept of the Anthropocene should simultaneously sharpen and broaden the focus of social innovation research to capture innovative ideas and initiatives that deliberately address integrated social-ecological issues. Single variable interventions, even if an original idea, cannot begin to address root causes, and may even accelerate the dynamics described in the Anthropocene concept. Yet, the typical focus on individual inventors and "hero" entrepreneurs in social innovation has led to a fixation on ideas and initiatives far too narrow in scope. Thus, the vast majority of the ideas that are currently documented in social innovation literature could be characterized as "single variable solutions."

An example of this challenge in practice includes the numerous initiatives developed or funded under the banner of social innovation that have focused on the use of digital technologies (e.g., Bria 2015) for a wide range of social and environmental issues. For instance, drones have been used to enhance animal and bird monitoring in parks and protected areas (Boss 2015), mobile technology is being utilized to improve access to maternal, newborn, and child health information and at times, treatment (e.g., Sandhu 2011, Bryson 2013), and mobile apps are increasing the accessibility to market prices for farmers (Lehr 2008). Missing from these discussions and analyses is consideration of the impacts of these initiatives if they are not clustered with other innovations that address the broader systemic impacts.

For the purpose of illustrating our point, we use the case of the Mobile Alliance for Maternal Action (MAMA) program that began in Bangladesh (http://www.unfoundation.org/what-wedo/issues/global-health/mobile-health-for-development/mama.html). The MAMA program includes 300 organizations in 70 countries, is projected to reach 1.4 million women, and uses mobile technology to provide text messages that provide timely information for pregnant women and new moms about healthy practices and what may be accessed through local health services. The program's reliance on the digital mobile technology is an incredible program that has already rapidly enhanced the educational initiatives being undertaken to support maternal, newborn, and child health. In terms of "bricolage," this case highlights the combination of existing health information, technology, and combines new actors, such as the private communication and mobile technology companies with international development aid agencies. Moreover, given the valuable role that new or different forms of knowledge can play in innovation, the transfer of knowledge to new mothers may generate a capacity for further social change, extending beyond newborn and child health. Therefore, we do not want to simply critique and diminish such efforts. However, we believe the integrated social-ecological challenges of the Anthropocene push us to further consider the reality that mobile technologies currently rely on nonrenewable resources, many of which are mined in the very countries where the maternal, newborn, and child health educational technology initiatives are targeting. Although regulatory standards are being made more stringent by many governments, and the mining industry itself is adopting standards to address the social and ecological impacts of their operations, the ecological degradation that results from mining are well understood (Plepys 2002).

Furthermore, the impacts of digital technologies are not only 
the up-front consumption of nonrenewable resources, but also the hazardous nature of e-waste. Again, many of these nations where the digital "social innovations" are being introduced, are the same areas of the world that have been targeted for e-waste transport from other countries (Iles 2004). Additionally, arguably one of the main beneficiaries of such solutions is the mobile phone companies themselves, often based in the Global North, and the digital innovations are then only further strengthening already dominant communications and technology companies (Wade 2002). We would argue that these anticipated and quite wellunderstood consequences run counter to a definition of social innovation that seeks to alter existing authority, power, and resource flows, norms and values, and social-ecological feedbacks that created the problem in the first place. Moreover, the innovative use of technology may address localized, short-term, immediate problems related to human well-being, but it does not address the long-term effects of social justice or impacts to the Earth's biosphere and its planetary boundaries and the need for humans to become a positive force on those systems.

By ensuring that social innovators actively reflect on the pathdependence of the system they are hoping to transform, in the context of the Anthropocene, and utilize heuristics such as bricolage, there is a better chance that such innovations will not reinforce the anthropogenic changes that led to the Anthropocene. This kind of critical reflection on the history of the system, in the context of the Anthropocene will fundamentally change the research and practice of social innovation. Bricolage is an approach that brings together very different ideas, concepts, philosophies and when paired with the notion of pathdependence can enable innovators to break from existing system pathways that may reinforce the Anthropocene. Initiatives that do not embody this kind of critical reflection on the pathdependence are not likely to be truly transformative.

\section{STRATEGIC IMPERATIVE \#3 - CONFRONTING THE SCALE CHALLENGE}

Social innovation is strongly oriented around the concept of scale, at times used interchangeably with the notion of having a significant impact (Evans and Clarke 2011, McPhedran Waitzer and Paul 2011, Bradach and Grindle 2014). Too often, the discussion focused on scale becomes primarily based on numbers, such as the need to diffuse and replicate a specific innovative product or program to the largest number of people possible, even when scholars recognize the need for more transformative change (e.g., Ross 2014). For instance, Schwab Foundation (2013:5) states "We need to unleash a whole new wave of social entrepreneurs and help existing models with proven impact grow to scale much more effectively." Murray et al. (2010) and Deacon (2016) highlight the numerous pathways to achieving such scale in public and private sectors, ranging from e-procurement to securing additional supply chains to expand production. This conception of scale is known as "scaling out" (Westley et al. 2014, Moore et al. 2015), and typically, an emphasis is placed on efficiency while ensuring social innovations suit a local context. This perspective for scaling innovation relies heavily on the approach used when scaling technological innovation, and reinforces a neoliberal growth paradigm as the basis for social innovation, thereby ignoring the real challenges associated with growth-fixated thinking in the Anthropocene. As Murray et al. (2010) warn, within this paradigm the tendency exists for incumbents to co- opt the innovation in order to more closely align with the current unsustainable system. A more promising discussion by Schwab Foundation and Bertha Centre (2017) note that a redefined version of scaling involves influencing the linkages and interconnections within systems, rather than focusing on extending reach to a large number of beneficiaries with a predefined solution.

The literature that has moved beyond scaling out, recognizes the need to scale "up," by altering institutional structures and processes (Westley and Antadze 2010, Westley et al. 2014) and scale "deep" to shift deeper, cultural beliefs, values, and ways of being (Moore et al. 2015). These ideas illuminate how the Anthropocene concept calls for an increased understanding of large-scale systemic changes at the social-ecological scales that matter; that is, having an impact at the scales that matter for the Anthropocene will require consideration of scaling out, up, and deep. How and under which conditions new ideas, experiments, and initiatives can have systemic impacts at the scales that matter for these concerns warrants social innovation scholars' attention.

What becomes especially pressing when considering the global scale patterns that the Anthropocene highlights is that the recent history of scaling solutions to solve global social and environmental problems has been highly problematic. Researchers have analyzed such attempts, including the Green Revolution cited earlier, but also the Green Revolution Africa (Daño 2007) and Farming the Sea - part of a "blue revolution" in the oceans using aquaculture (Environmental Justice Foundation 2004) - and criticized them for the manner in which they repeat past patterns.

Another example involves the uptake of biofuels. Biofuels emerged as an important and promising alternative to fossil fuels, thus their increased use was, and is, promoted as a way to tackle climate change (Tirado et al. 2010). At times, biofuels have been identified as a social innovation, and categorized as worthy of investment (e.g., Endres 2012, Martin 2016). When adopted locally or by only small groups of people within a city or community, biofuels showed great promise. However, when biofuels became more widely adopted at the global level in the mid-2000s, numerous negative effects followed that were generally unexpected to the original small-scale groups experimenting with this fuel source. Specifically, the shifts in land use to grow biofuel crops had significant impacts on water resources, biological diversity, and created increased food security issues now that land was being used to cultivate fuels instead of food (Grau and Aide 2008). Furthermore, several instances of a state government and/ or multinational corporations acquiring land to devote to biofuel crops have been identified as involving land grabbing, where local communities were displaced without prior, informed consent, compensation, and at times, directly through violence or threats (Aguilar-Støen 2016). Much of this land has been documented as being traditionally used for subsistence farming, and when converted to biofuels, food insecurity followed for the most marginal populations, which in turn has led to increased inequalities and conflicts (Borras and Franco 2010). The challenge is that the attempt to scale this particular innovation was eventually embraced by, and quickly entrenched within, industrial agriculture and forestry production systems. The consequence, as Dauvergne and Neville (2010) highlight, is that 
biofuels simply became a discourse about sustainability and innovation that only reproduced and reinforced existing concerns about the energy system, including the market-based approaches to environmental governance, and the problem of historical statesociety land tenure.

Without paying attention to social and ecological linkages across multiple scales when scaling an innovation, we will merely shift the problems to other sectors or to future generations. If the social-ecological relationships are missing, evidence indicates that we can anticipate that innovative solutions will reproduce problems rather than resolve them. The question remains about how a social innovator can "see" the social-ecological linkages across scales in which they may be directly working, and how can research help to reveal those linkages across scales that matter in the Anthropocene. For instance, understanding the connections between climatic systems, food price volatility, and social unrest is crucial to mitigate and minimize both social and environmental risks at local to global levels (World Economic Forum 2015). Research has begun to identify the notion of telecouplings, defined as the often hidden connections between problems or vulnerabilities in different places (Adger et al. 2009, Liu et al. 2013). Although these are challenging at any scale, telecouplings are particularly problematic or difficult to make visible at a global scale, which many scholars have demonstrated when mapping and describing the Anthropocene (Galaz 2014, Brondizio et al. 2016, Liu et al. 2016). For example Eakin et al. (2009) use the case study of coffee production in Vietnam and Mexico to show how the consequences of food production are not accounted for in governance institutions across more distant and temporal spatial scales.

Despite the challenge these hidden linkages create, it is unlikely that a social innovation will have a system-changing effect if it does not tap into and rewire these social-ecological teleconnections or relationships. In addition to requiring social innovation researchers to begin to attend to social-ecological system scales and telecouplings in their investigations, the concept of the Anthropocene also sets new temporal constraints to be considered in social innovation research. Rockström et al. (2009) emphasizes the need for speed to deal with the large scale changes associated with the Anthropocene. The social innovation literature likewise recognizes the urgency for social change in the face of challenges such as climate change (e.g., Murray et al. 2010). Yet, analyses of historical case studies have demonstrated that the arc of a social innovation that is likely to cause systemic, transformative change may take as long as 150 years (Westley et al. 2016). Therefore, the Anthropocene construct highlights a challenge that is worthy of consideration by social innovation scholars, but also by the philanthropic investors and practitioners pushing for social change; that is, how can we achieve change at the scales that matter, in terms of scope, and in terms of time scales? The vast majority of case studies in social innovation literature examine initiatives that are less than a decade old. Thus, while they may indicate that some "seeds of change" have been planted, there is little long-term assessment about the role of temporal scales with regard to the dynamics of these socially innovative initiatives.

Related to this issue though, is the paradoxical tension raised by the need for speed and the desire for a "good" Anthropocene that keeps social and ecological justice issues at the forefront of new social innovations. The same social innovations that may be fast, or that might match the temporal scales that matter to the Anthropocene, may not necessarily be those that are just or desirable. Social innovation research needs to confront this tension to grapple with the many normative implications that the Anthropocene construct reveals. For example, Merrie and Olsson (2014) demonstrated how the idea of marine spatial planning that was primarily developed in Australia, Belgium, and the UK as a tool for linking social and ecological dynamics was scaled-out and spread across the world. But as the approach to planning became adopted by various countries, the linkage between the social and ecological, and what appeared "good" about the innovation, was actually lost in some instances as it spread to other locations. This example reinforces that responding to Anthropocene challenges quickly, puts the spotlight on the additional challenge of the normative decisions associated with determining what is and will be "good," with the usual considerations of "for whom and for what," and how to retain those elements at scales that matter to all people and the planet (Schmidt et al. 2016).

In summary, we contend that social innovation scholarship and practice needs to grapple with the cross-scalar nature of the issues associated with the Anthropocene, which requires moving away from thinking about impact and "scaling" only as growth and diffusion. Scales may be temporal, biophysical, or based on social organization, but understanding which scales matter, and when they matter, remains a question for exploration. The concept of the Anthropocene signals that humans and the planet may not have the same length of time that was available for social innovations in the past. Time always raises a paradoxical tension; transformative change may be urgently needed, but the process of reconnecting humans and the planet in new, just, and sustainable ways is not work that is likely to be easy or quick. The first step though is to begin to explore options, as opposed to neglecting what the Anthropocene highlights.

\section{CONCLUSION}

As stated earlier, the academic field and the practice of social innovation is growing. A quick glance at the many articles, initiatives, and reports cited here demonstrate that momentum is building among academic scholars and social entrepreneurs throughout the world who are attempting to understand and change the "business as usual" model, in social services, business operations, and in community development programs. Social innovation is a powerful concept for understanding how social relationships change but the question remains if it can also help provide paths forward for fundamentally changing people-planet relationships.

We believe so, and in this article we have argued that although criticisms abound about the concept of the Anthropocene, the construct does draw attention to the linked nature of the global ecological and social trends about which there is little argument. The idea that we are living in the era of the Anthropocene may still be a heuristic device, but as such it is still a game changer for social innovation theory and practice. In particular, we argue that the concept points to three areas of thought that are strategically imperative and must be accelerated if social innovation theory and practice is to prove transformative and respond to the challenges associated with the Anthropocene. First, we contend that the current debate on social innovation for sustainability lacks a deeper focus on human-environmental interactions and 
feedbacks necessary to understand and achieve large-scale change and transformations to global sustainability. Second, social innovation research must move toward confronting the need for bricolage that includes social and ecological elements to address the integrated and systemic nature of the Anthropocene.

Finally, we put forward the idea that the cross-scalar nature of the Anthropocene requires revisiting both the scope and temporal nature of social innovations that are most typically focused upon by scholars and funders alike. Social innovation that will lead to transformation is not likely to be merely concerned with replication or the adaptation of existing ideas or "scaling-out."

Finding ways to meet the physical and social needs of a growing human population, particularly those marginalized and made vulnerable by current economic arrangements is a laudable goal. But short-term, single variable interventions do not automatically lead to sustainability or resilience. Previous attempts such as the green revolution and biofuel advancement should make us aware that the "humans first" approach can be risky for many reasons, one of which is human dependence on functioning ecosystems. Therefore, we emphasize the necessity of social innovation research and practice that can (re)connect people and the planet in fundamentally new ways. We need to be able to address questions not only on how social innovations will change social dimensions such as the flows of power and authority that underpin social inequality, but also how to generate different landscapes and flows of ecosystem services, maintain functional groups of multiple species and response diversity, support spatial resilience, and steer away from critical thresholds. Only then can we move away from generating innovations that, at best, reduce negative impacts, and at worst, create long-term problems in other areas, toward approaches that help humanity become a positive force on the planet and create a good Anthropocene.

The concept of the Anthropocene challenges social innovation researchers to recognize that nations and a society no longer have the luxury to separate social challenges such as poverty, equality, and employment from the planetary challenges of biodiversity, greenhouse gas emissions, finite resources, and more. This applies not only to the complex challenge of climate change, but also to questions of resource depletion, biodiversity, and other environmental issues. An important part in healing the balance and relationship between people and the planet lies in working actively with bricolage solutions that address innovations in a broader social-ecological systems perspective.

The task ahead is to build a new integrated approach to social innovation. Although this will not be easy, it is critical. We hope the extensive and growing network of researchers and practitioners in the field of social innovation can join us in understanding the possibilities for a changed "game."

Responses to this article can be read online at: http://www.ecologyandsociety.org/issues/responses. php/9310

\section{Acknowledgments:}

This research has been supported by the Stockholm Resilience
Centre through grants from the Foundation for Strategic Environmental Research (Mistra) and the Swedish International Development Agency (Sida). We appreciate the thoughtful and constructive comments by two anonymous reviewers, and the feedback that we received from TRANSIT project team members on earlier versions of this paper.

\section{LITERATURE CITED}

Acheson, J. M. 1988. The lobster gangs of Maine, University Press of New England, Lebanon, New Hampshire, USA.

Adger, W. N., H. Eakin, and A. Winkels. 2009. Nested and teleconnected vulnerabilities to environmental change. Frontiers in Ecology and the Environment 7:150-157. http://dx.doi. org/10.1890/070148

Aguilar-Støen, M. 2016. Beyond transnational corporations, food and biofuels: the role of extractivism and agribusiness in land grabbing in Central America. Forum for Development Studies 43(1):155-175. http://dx.doi.org/10.1080/08039410.2015.1134641

Antadze, N., and F. R. Westley. 2012. Impact metrics for social innovation: barriers or bridges to radical change? Journal of Social Entrepreneurship 3(2):133-150. http://dx.doi. org/10.1080/19420676.2012.726005

Arthur, B. 2009. The nature of technology: what it is and how it evolves. Penguin, London, UK.

Avelino, F., and J. Wittmayer. 2014. Exploring tools for facilitating transformative social innovation (TSI): lessons from transition facilitation methods. TRANSIT: EU SSH.2013.3.2-1 Grant agreement no: 613169. DRIFT, Maastricht, The Netherlands.

Avelino, F., J. Wittmayer, A. Haxeltine, R. Kemp, T. O'Riordan, P. Weaver, D. Loorbach, and J. Rotmans. 2014. Game-changers and transformative social innovation. The case of the economic crisis and the new economy. TRANSIT: EU SSH.2013.3.2-1 Grant agreement no: 613169. TRANSIT working paper series, Rotterdam, The Netherlands. [online] URL: http://www. transitsocialinnovation.eu/content/original/TRANSIT $\% 20$ outputs $/ 91 \%$ 20Gamechangers TSI_Avelino etal TRANSIT workingpaper 2014. pdf

Barefoot College. 2016. A path to development led by communities. Barefoot College, Ajmer, India. [online] URL: http://www. barefootcollege.org/approach/

Bennett, E. M., M. Solan, R. Biggs, T. McPhearson, A. V. Norström, P. Olsson, L. Pereira, G. D. Peterson, C. RaudseppHearne, F. Biermann, S. R. Carpenter, et al. 2016. Bright spots: seeds of a good Anthropocene. Frontiers in Ecology and the Environment 14(8):441-448. http://dx.doi.org/10.1002/fee.1309

Biermann, F. 2014. The Anthropocene: a governance perspective. Anthropocene Review 1(1):57-61. http://dx.doi.org/10.1177/2053$\underline{019613516289}$

Biggs, R., F. R. Westley, and S. R. Carpenter. 2010. Navigating the back loop: fostering social innovation and transformation in ecosystem management. Ecology and Society 15(2):9. http://dx. doi.org/10.5751/es-03411-150209

Booth, A. L., and N. W. Skelton. 2011. "You spoil everything!" Indigenous peoples and the consequences of industrial development in British Columbia. Environment, Development and 
Sustainability 13(4):685-702. http://dx.doi.org/10.1007/s10668-011-9284$\underline{\mathrm{X}}$

Borras, S. M., Jr., and J. Franco. 2010. Towards a broader view of the politics of global land grabbing: rethinking land issues, reframing resistance. International Institute of Social Studies, The Hague, The Netherlands.

Boss, S. 2015. Taking flight for conservation. Stanford Social Innovation Review 13(11-12).

Bradach, J., and A. Grindle. 2014. Emerging pathways to transformative scale. Stanford Social Innovation Review Spring (Supplement):7-11.

Bria, F. 2015. Growing a digital social innovation ecosystem for Europe. European Union, Brussels, Belgium.

Brondizio, E. S., K. O’Brien, X. Bai, F. Biermann, W. Steffen, F. Berkhout, C. Cudennec, M. C. Lemos, A. Wolfe, J. PalmaOliveira, and C. T. A. Chen. 2016. Re-conceptualizing the Anthropocene: a call for collaboration. Global Environmental Change. 39:318-327. http://dx.doi.org/10.1016/j.gloenvcha.2016.02.006

Bryson, D. 2013. Texting for change. Stanford Social Innovation Review 11(3):61-62.

Cajaiba-Santana, G. 2014. Social innovation: moving the field forward: a conceptual framework. Technological Forecasting and Social Change 82:42-51. http://dx.doi.org/10.1016/j.techfore.2013.05.008

Carmin, J., and J. Ageyman. 2011. Environmental inequalities beyond borders: local perspectives on global injustices. MIT Press, Cambridge, Massachusetts, USA.

Castree, N. 2015. Geographers and the discourse of an earth transformed: influencing the intellectual weather or changing the intellectual climate? Geographical Research 53:244-254. http://dx. doi.org/10.1111/1745-5871.12125

Cinner, J. E. 2011. Social-ecological traps in reef fisheries. Global Environmental Change 21(3):835-839. http://dx.doi.org/10.1016/ j.gloenvcha.2011.04.012

Cleaver, H. M. 1972. The contradictions of the green revolution. American Economic Review 62(1-2):177-186.

Cook, B. R., L. A. Rickards, and I. Rutherford. 2015. Geographies of the Anthropocene. Geographical Research 53 (3):231-243. http://dx.doi.org/10.1111/1745-5871.12127

Corner, P. D., and M. Ho. 2010. How opportunities develop in social entrepreneurship. Entrepreneurship Theory and Practice 34 (4):635-659. http://dx.doi.org/10.1111/j.1540-6520.2010.00382.x

Crutzen, P. J. 2002. Geology of mankind. Nature 415:23. http:// dx.doi.org/10.1038/415023a

Crutzen, P. J., and E. F. Stoermer. 2000. The Anthropocene. Royal Swedish Academy of Sciences, Stockholm, Sweden.

Dacin, P. A., M. T. Dacin, and M. Matear. 2010. Social entrepreneurship: Why we don't need a new theory and how we move forward from here. Academy of Management Perspectives 24(3):37-57.

Daño, E. C. 2007. Unmasking the new green revolution in Africa: motives, players and dynamics. EED, Third World Network, African Center for Biosafety, Richmond, South Africa.
Dauvergne, P., and K. J. Neville. 2010. Forests, food, and fuel in the tropics: the uneven social and ecological consequences of the emerging political economy of biofuels. Journal of Peasant Studies 37(4):631-660. http://dx.doi.org/10.1080/03066150.2010.512451

Davison, A. 2015. Beyond the mirrored horizon: modern ontology and amodern possibilities in the Anthropocene. Geographical Research 53(3):298-305. http://dx.doi. org/10.1111/1745-5871.12123

Deacon, C. 2016. What does it take to go big? Insights on scaling social innovation from the Centre for Social Action Innovation Fund. NESTA, London, UK.

Dees, G., B. B. Anderson, and J. Wei-Skillern. 2004. Scaling social impact: strategies for spreading social innovations. Stanford Social Innovation Review 1(4):24-33.

Dorado, S. 2005. Institutional entrepreneurship, partaking, and convening. Organization Studies 26(3):385-414. http://dx.doi. org/10.1177/0170840605050873

Eakin, H., A. Winkels, and J. Sendzimir. 2009. Nested vulnerability: exploring cross-scale linkages and vulnerability teleconnections in Mexican and Vietnamese coffee systems. Environmental Science \& Policy 12:398-412. http://dx.doi. org/10.1016/j.envsci.2008.09.003

Ellis, E. C. 2011. A world of our making. New Scientist 210:26-27. http://dx.doi.org/10.1016/s0262-4079(11)61376-6

Endres, J. M. 2012. Legitimacy, innovation, and harmonization: precursors to operationalizing biofuels sustainability standards. Southern Illinois University Law Journal 37:1.

Enfors, E. 2013. Social-ecological traps and transformations in dryland agro-ecosystems: using water system innovations to change the trajectory of development. Global Environmental Change 23(1):51-60. http://dx.doi.org/10.1016/j.gloenvcha.2012.10.007

Environmental Justice Foundation. 2004. Farming the sea, costing the Earth: why we must green the blue revolution. Environmental Justice Foundation, London, UK.

European Commission. 2016. European social innovation competition. European Commission, Brussels, Belgium. [online] URL: https://ec.europa.eu/growth/industry/innovation/policy/ social/competition en

Evans, S. H., and P. Clarke. 2011. Disseminating orphan innovations. Stanford Social Innovation Review 9(1):42-47.

Folke, C., R. Biggs, A. V. Norström, B. Reyers, and J. Rockström. 2016. Social-ecological resilience and biosphere-based sustainability science. Ecology and Society 21(3):41. http://dx.doi.org/10.5751/ es-08748-210341

Freebairn, D. K. 1995. Did the green revolution concentrate incomes? A quantitative study of research reports. World Development 23(2):265-279. http://dx.doi.org/10.1016/0305-750x (94)00116-g

Gaffney, O., and W. Steffen. 2017. The Anthropocene equation. Anthropocene Review 4:1-9. http://dx.doi.org/10.1177/2053019616688022

Galaz, V., editor. 2014. Global environmental governance, 
technology and politics: the Anthropocene gap. Edward Elgar, Cheltenham, UK. http://dx.doi.org/10.4337/9781781955550

Geobey, S., F. R. Westley, and O. Weber. 2012. Enabling social innovation through developmental social finance. Journal of Social Entrepreneurship 3(2):151-165. http://dx.doi. org/10.1080/19420676.2012.726006

Godfray, H. C. J., J. R. Beddington, I. R. Crute, L. Haddad, D. Lawrence, J. F. Muir, J. Pretty, S. Robinson, S. M. Thomas, and C. Toulmin. 2010. Food security: the challenge of feeding 9 billion people. Science 327(5967):812-818. http://dx.doi.org/10.1126/ science. 1185383

Goldstein, J., J. K. Hazy, and J. Silberstang. 2010. A complexity science model of social innovation in social enterprise. Journal of Social Entrepreneurship 1(1):101-125. http://dx.doi. org/10.1080/19420671003629763

Grabowski, J. H., E. J. Clesceri, A. J. Baukus, J. Gaudette, M. Weber, and P. O. Yund. 2010. Use of herring bait to farm lobsters in the Gulf of Maine. PLoS ONE 5(4):e10188. http://dx.doi. org/10.1371/journal.pone.0010188

Grau, H. R., and M. Aide. 2008. Globalization and land-use transitions in Latin America. Ecology and Society 13(2):16. http:// dx.doi.org/10.5751/es-02559-130216

Hajer, M., M. Nilsson, K. Raworth, P. Bakker, F. Berkhout, Y. De Boer, J. Rockström, K. Ludwig, and M. Kok. 2015. Beyond cockpit-ism: four insights to enhance the transformative potential of the sustainable development goals. Sustainability 7 (2):1651-1660. http://dx.doi.org/10.3390/su7021651

Hibbard, K. A., P. Crutzen, E. F. Lambin, D. Liverman, N. J. Mantua, J. R. Mcneill, B. Messerli, and W. Steffen. 2007. The great acceleration. Pages 341-378 in R. Costanza, L. J. Graumlich, and W. Steffen, editors. Sustainability or collapse? An integrated history and future of people on Earth. MIT Press, Cambridge, Massachusetts, USSA.

Homer-Dixon, T. F. 1999. Environment, scarcity, and violence. Princeton University Press, Princeton, New Jersey, USA. http:// dx.doi.org/10.1515/9781400822997

Howaldt, J., and R. Kopp. 2012. Shaping social innovation by social research. Pages 43-55 in H.-W. Franz, J. Hochgerner, and J. Howaldt, editors. Challenge social innovation. Springer, Berlin, Germany. http://dx.doi.org/10.1007/978-3-642-32879-4 3

Howaldt, J., and M. Schwarz. 2016. Social innovation and its relationship to social change. TU Dortmund University, Dortmund, Germany.

Iles, A. 2004. Mapping environmental justice in technology flows: computer waste impacts in Asia. Global Environmental Politics 4:76-107. http://dx.doi.org/10.1162/glep.2004.4.4.76

Jackson, J. B. C., M. X. Kirby, W. H. Berger, K. A. Bjorndal, L. W. Botsford, B. J. Bourque, R. H. Bradbury, R. Cooke, J. Erlandson, J. A. Estes, T. P. Hughes, S. Kidwell, C. B. Lange, H. S. Lenihan, J. M. Pandolfi, C. H. Peterson, R. S. Steneck, M. J. Tegner, and R. R. Warner. 2001. Historical overfishing and the recent collapse of coastal ecosystems. Science 293:629-637. http:// dx.doi.org/10.1126/science.1059199

Kinzig, A. P., P. Ryan, M. Etienne, H. Allison, T. Elmqvist, and
B. H. Walker. 2006. Resilience and regime shifts: assessing cascading effects. Ecology and Society 11(1):20. http://dx.doi. org/10.5751/es-01678-110120

Leach, M., K. Raworth, and J. Rockström. 2013. Between social and planetary boundaries: navigating pathways in the safe and just space for humanity. Pages 84-89 in International Social Science Council/Unesco, editor. World social science report 2013: changing global environments. OECD and UNESCO, Paris, France. http://dx.doi.org/10.1787/9789264203419-10-en

Lehr, D. 2008. Dialing for development. Stanford Social Innovation Review 6(4):44-49.

Lenton, T. M., H. Held, E. Kriegler, J. W. Hall, W. Lucht, S. Rahmstorf, and H. J. Schellnhuber. 2008. Tipping elements in the Earth's climate system. Proceedings of the National Academy of Sciences. 105:1786-1793. http://dx.doi.org/10.1073/pnas.0705414105

Lewis, S. L., and M. A. Maslin. 2015. Defining the Anthropocene. Nature 519:171-180. http://dx.doi.org/10.1038/nature14258

Liu, J., V. Hull, M. Batistella, R. DeFries, T. Dietz, F. Fu, T. W. Hertel, R. C. Izaurralde, E. F. Lambin, S. Li, L. A. Martinelli, W. J. McConnell, E. F. Moran, R. Naylor, Z. Ouyang, K. R. Polenske, A. Reenberg, G. de Miranda Rocha, C. S. Simmons, P. H. Verburg, P. M. Vitousek, F. Zhang, and C. Zhu. 2013. Framing sustainability in a telecoupled world. Ecology and Society 18 (2):26. http://dx.doi.org/10.5751/es-05873-180226

Liu, J., W. Yang, and S. Li. 2016. Framing ecosystem services in the telecoupled Anthropocene. Frontiers in Ecology and the Environment 14(1):27-36. http://dx.doi.org/10.1002/16-0188.1

Loorbach, D., F. Avelino, A. Haxeltine, J. M. Wittmayer, T. O'Riordan, P. Weaver, and R. Kemp. 2016. The economic crisis as a game changer? Exploring the role of social construction in sustainability transitions. Ecology and Society 21(4):15. http://dx. doi.org/10.5751/es-08761-210415

Lövbrand, E., S. Beck, J. Chilvers, T. Forsyth, J. Hedrén, M. Hulme, R. Lidskog, and E. Vasileiadou. 2015. Who speaks for the future of Earth? How critical social science can extend the conversation on the Anthropocene. Global Environmental Change 32:211-218.

Lovelock, J. E. 1972. Gaia as seen through the atmosphere. Atmospheric Environment 6:579-580. http://dx.doi.org/10.1016/0004-6981 (72)90076-5

Mair, J., and I. Marti. 2009. Entrepreneurship in and around institutional voids: a case study from Bangladesh. Journal of Business Venturing 24(5):419-435. http://dx.doi.org/10.1016/j. jbusvent.2008.04.006

Malm, A., and A. Hornborg. 2014. The geology of mankind? A critique of the Anthropocene narrative. Anthropocene Review 1:62-69. http://dx.doi.org/10.1177/2053019613516291

Manuel-Navarrete, D., J. J. Kay, and D. Dolderman. 2004. Ecological integrity discourses: linking ecology with cultural transformation. Human Ecology Review 11:215-229.

Martin, M. 2016. Impact investing: four opportunities for 2016. Stanford Social Innovation Review 14.

Martinez, P. 2010. Full economic citizenship. Ashoka India, Bangalore, India. [online] URL: https://india.ashoka.org/fulleconomic-citizenship 
Mascarenhas, M. 2007. Where the waters divide: First Nations, tainted water and environmental justice in Canada. Local Environment 12(6):565-577. http://dx.doi.org/10.1080/13549830701657265

McCarthy, D. D. P., M. Millen, M. Boyden, E. Alexiuk, G. S. Whitelaw, L. Viswanathan, D. Larkman, G. Rowe, and F. R. Westley. 2014. A First Nations-led social innovation: a moose, a gold mining company, and a policy window. Ecology and Society 19(4):2. http://dx.doi.org/10.5751/es-06771-190402

McGowan, K., and F. R. Westley. 2015. At the root of change: the history of social innovation. Pages 52-68 in A. Nicholls, J. Simon, and M. Gabriel, editors. New frontiers in social innovation research. Palgrave Macmillan, Basingstoke, UK. http://dx.doi. org/10.1057/9781137506801_3

McPhedran Waitzer, J., and R. Paul. 2011. Scaling social impact: when everybody contributes, everybody wins. Innovations 6 (2):143-155. http://dx.doi.org/10.1162/INOV a 00074

Merrie, A., and P. Olsson. 2014. An innovation and agency perspective on the emergence and spread of marine spatial planning. Marine Policy 44:366-374. http://dx.doi.org/10.1016/j. marpol.2013.10.006

Moore, M.-L., D. Riddell, and D. Vocisano. 2015. Scaling out, scaling up, scaling deep: strategies of non-profits in advancing systemic social innovation. Journal of Corporate Citizenship 58:67-84. http://dx.doi.org/10.9774/GLEAF.4700.2015.ju.00009

Moore, M.-L., and O. Tjornbo. 2012. From coastal timber supply area to Great Bear Rainforest: exploring power in a socialecological governance innovation. Ecology and Society 17(4):26. http://dx.doi.org/10.5751/ES-05194-170426

Moore, M. L., O. Tjornbo, E. Enfors, C. Knapp, J. Hodbod, J. A. Baggio, A. Norström, P. Olsson, and D. Biggs. 2014. Studying the complexity of change: toward an analytical framework for understanding deliberate social-ecological transformations. Ecology and Society 19(4):54. http://dx.doi.org/10.5751/ es-06966-190454

Moore, M.-L., and F. R. Westley. 2011. Surmountable chasms: networks and social innovation for resilient systems. Ecology and Society 16(1):5. http://dx.doi.org/10.5751/es-03812-160105

Moore, M.-L., F. R. Westley, and A. Nicholls. 2012b. The social finance and social innovation nexus. Journal of Social Entrepreneurship 3(2):115-132. http://dx.doi.org/10.1080/194206$\underline{76.2012 .725824}$

Moore, M.-L., F. R. Westley, O. Tjornbo, and C. Holroyd. $2012 a$. The loop, the lens, and the lesson: using resilience theory to examine public policy and social innovation. Pages 89-113 in A. Nicholls and A. Murdoch, editors. Social innovation: blurring boundaries to reconfigure markets. Palgrave MacMillan, Basingstoke, UK. http://dx.doi.org/10.1057/9780230367098_4

Moulaert, F., D. MacCallum, A. Mehmood, and A. Hamdouch, editors. 2013. The international handbook on social innovation: collective action, social learning and transdisciplinary research. Edward Elgar, Cheltenham, UK. http://dx.doi.org/10.4337/978$\underline{1849809993}$

Mulgan, G. 2006. The process of social innovation. Innovations: Technology, Governance, Globalization 1(2):145-162. http://dx. doi.org/10.1162/itgg.2006.1.2.145
Mulgan, G., S. Tucker, R. Ali, and B. Sanders. 2007. Social innovation: what it is, why it Matters, and how it can be accelerated. Basingstoke Press, London, UK.

Mumford, M. D. 2002. Social innovation: ten cases from Benjamin Franklin. Creativity Research Journal 14(2):253-266. http://dx.doi.org/10.1207/s15326934cri1402 11

Mumford, M. D., and P. Moertl. 2003. Cases of social innovation: lessons from two innovations in the 20th Century. Creativity Research Journal 15(2-3):261-266. http://dx.doi.org/10.1080/104$\underline{00419.2003 .9651418}$

Murray, R., J. Caulier-Grice, and G. Mulgan. 2010. The open book of social innovation. The Young Foundation, London, UK.

Nicholls, A., and A. Murdock, editors. 2012. Social innovation: blurring boundaries to reconfigure markets. Palgrave MacMillan, Basingstoke, UK.

Nicholls, A., J. Simon, and M. Gabriel, editors. 2015. New frontiers in social innovation research. Palgrave Macmillan, Basingstoke, UK. http://dx.doi.org/10.1057/9781137506801

Norström, A. V., A. Dannenberg, G. McCarney, M. Milkoreit, F. Diekert, G. Engström, R. Fishman, J. Gars, E. Kyriakopoolou, V. Manoussi, K. Meng, M. Metian, M. Sanctuary, M. Schlüter, M. Schoon, L. Schultz, and M. Sjöstedt. 2014. Three necessary conditions for establishing effective sustainable development goals in the Anthropocene. Ecology and Society 19(3):8. http:// dx.doi.org/10.5751/es-06602-190308

Olsson, P., and V. Galaz. 2012. Social-ecological innovation and transformation. Pages 223-247 in A. Nicholls and A. Murdoch, editors. Social innovation: blurring boundaries to reconfigure markets. Palgrave MacMillan, Basingstoke, UK. http://dx.doi. org/10.1057/9780230367098 10

Osburg, T., and R. Schmidpeter, editors. 2013. Social innovation: solutions for a sustainable future. Springer, Heidelberg, Germany. http://dx.doi.org/10.1007/978-3-642-36540-9

Phillips, W., H. Lee, A. Ghobadian, N. O'Regan, and P. James. 2015. Social innovation and social entrepreneurship: a systematic review. Group \& Organization Management 40(3):428-461. http:// dx.doi.org/10.1177/1059601114560063

Phills, J. A., K. Deiglmeier, and D. T. Miller. 2008. Rediscovering social innovation. Stanford Social Innovation Review 6(4):34-43.

Plepys, A. 2002. The grey side of ICT. Environmental Impact Assessment Review 22:509-523. http://dx.doi.org/10.1016/ $\underline{\mathrm{S} 0195-9255(02) 00025-2}$

Porter, M. E., and M. R. Kramer. 2011. Creating shared value. Harvard Business Review Jan-Feb:62-77.

Pulford, L. 2010. This is European social innovation. European Union, Brussels, Belgium.

Rockström, J., W. Steffen, K. Noone, Å. Persson, F. Stuart Chapin III, E. F. Lambin, T. M. Lenton, M. Scheffer, C. Folke, H. J. Schellnhuber, B. Nykvist, C. A. De Wit, T. Hughes, S. van der Leeuw, H. Rodhe, S. Sörlin, P. K. Snyder, R. Costanza, U. Svedin, M. Falkenmark, L. Karlberg, R. W. Corell, V. J. Fabry, J. Hansen, B. Walker, D. Liverman, K. Richardson, P. Crutzen, and J. A. Foley. 2009. A safe operating space for humanity. Nature 461:472-475. http://dx.doi.org/10.1038/461472a 
Ross, R. K. 2014. We need more scale, not more innovation. Stanford Social Innovation Review Spring(Supplement):18-19.

Roy, B., and J. Hartigan. 2008. Empowering the rural poor to develop themselves: the Barefoot Approach. Innovations 3 (2):67-93. http://dx.doi.org/10.1162/itgg.2008.3.2.67

Sandhu, J. S. 2011. Opportunities in mobile health. Stanford Social Innovation Review 9(4):14-17.

Schmidt, J. J., P. G. Brown, and C. J. Orr. Ethics in the Anthropocene: a research agenda. Anthropocene Review 3 (3):188-200. http://dx.doi.org/10.1177/2053019616662052

Schwab Foundation for Social Entrepreneurship. 2013. Breaking the binary: policy guide to scaling social innovation. Schwab Foundation for Social Entrepreneurship, Geneva, Switzerland.

Schwab Foundation and Bertha Centre for Social Innovation and Entrepreneurship, University of Cape Town. 2017. Beyond organizational scale: how social entrepreneurs create systems change. World Economic Forum, Geneva, Switzerland.

Seyfang, G., and A. Haxeltine. 2012. Growing grassroots innovations: exploring the role of community-based initiatives in governing sustainable energy transitions. Environment and Planning C: Politics and Space 30(3):381-400. http://dx.doi. org/10.1068/c10222

Seyfang, G., and A. Smith. 2007. Grassroots innovations for sustainable development: towards a new research and policy agenda. Environmental Politics 16(4):584-603. http://dx.doi. org/10.1080/09644010701419121

Shaw, E., and A. de Bruin. 2013. Reconsidering capitalism: the promise of social innovation and social entrepreneurship? International Small Business Journal 31(7):737-746. http://dx.doi. org/10.1177/0266242613497494

Shiva, V. 2016. The violence of the green revolution: Third World agriculture, ecology, and politics. University Press of Kentucky, Lexington, Kentucky, USA.

Skoll Foundation. 2015. Environmental sustainability. Skoll Foundation, Palo Alto, California, USA. [online] URL: http:// skoll.org/about/issue-areas/environmental-sustainability/

Smith, A., A. Stirling, and F. Berkhout. 2005. The governance of sustainable socio-technical transitions. Research Policy 34 (10):1491-1510. http://dx.doi.org/10.1016/j.respol.2005.07.005

Spaargaren, G., and A. P. J. Mol. 2008. Greening global consumption: redefining politics and authority. Global Environmental Change 18(3):350-359. http://dx.doi.org/10.1016/ j.gloenvcha.2008.04.010

Steffen, W., W. Broadgate, L. Deutsch, O. Gaffney, and C. Ludwig. 2015. The trajectory of the Anthropocene: the great acceleration. Anthropocene Review 2:81-98. http://dx.doi.org/10.1177/205301$\underline{9614564785}$

Steffen, W., Å. Persson, L. Deutsch, J. Zalasiewicz, M. Williams, K. Richardson, C. Crumley, P. Crutzen, C. Folke, L. Gordon, M. Molina, V. Ramanathan, J. Rockström, M. Scheffer, H. J. Schellnhuber, and U. Svedin. 2011. The Anthropocene: from global change to planetary stewardship. AMBIO. 40:739-761. http://dx.doi.org/10.1007/s13280-011-0185-x
Steffen, W., R. A. Sanderson, P. D. Tyson, J. JäGer, P. A. Matson, B. Moore III, F. Oldfield, K. Richardson, H. J. Schellnhuber, B. L. Turner, and R. J. Wasson. 2005. Global change and the Earth system: a planet under pressure. Springer-Verlag, Berlin, Germany. http://dx.doi.org/10.1007/b137870

Steneck, R. S., T. P. Hughes, J. E. Cinner, W. N. Adger, S. N. Arnold, F. Berkes, S. A. Boudreau, K. Brown, C. Folke, L. Gunderson, et al. 2011. Creation of a gilded trap by the high economic value of the Maine lobster fishery. Conservation Biology 25(5):904-912. http://dx.doi.org/10.1111/j.1523-1739.2011.01717. $\underline{\mathrm{X}}$

Sundberg, J. 2006. Conservation, globalization, and democratization: exploring the contradictions in the Maya Biosphere Reserve, Guatemala. Pages 259-276 in K. S. Zimmerer, editor. Globalization and new geographies of conservation. University of Chicago Press, Chicago, Illinois, USA.

Taylor, P. L. 2010. Conservation, community, and culture? New organizational challenges of community forest concessions in the Maya Biosphere Reserve of Guatemala. Journal of Rural Studies 26(2):173-184. http://dx.doi.org/10.1016/j.jrurstud.2009.09.006

Tirado, M. C., M. J. Cohen, N. Aberman, J. Meerman, and B. Thompson. 2010. Addressing the challenges of climate change and biofuel production for food and nutrition security. Food Research International 43:1729-1744. http://dx.doi.org/10.1016/j. foodres.2010.03.010

Tjornbo, O., and F. R. Westley. 2012. Gamechangers: the big green challenge and the role of challenge grants in social innovation. Journal of Social Entrepreneurship 3(2):166-183. http://dx.doi. org/10.1080/19420676.2012.726007

Vernadsky, W. I. 1945. The biosphere and the noösphere. American Scientist 33:1-12.

Wade, R. H. 2002. Bridging the digital divide: new route to development or new form of dependency? Global Governance 8 (4):443-466.

Walker, B., and F. Westley. 2011. Perspectives on resilience to disasters across sectors and cultures. Ecology and Society 16(2):4. http://dx.doi.org/10.5751/es-04070-160204

Westley, F. R. 2013. Social innovation and resilience: how one enhances the other. Stanford Social Innovation Review 11(3):6-8.

Westley, F. R., and N. Antadze. 2010. Making a difference: strategies for scaling social innovation for greater impact. Public Sector Innovation Journal 15(2):2.

Westley, F. R., N. Antadze, D. Riddell, K. Robinson, and S. Geobey. 2014. Five configurations for scaling up social innovation: case examples of nonprofit organizations from Canada. Journal of Applied Behavioral Science 50(3):1-27. http:// dx.doi.org/10.1177/0021886314532945

Westley, F. R., K. A. McGowan, N. Antadze, J. Blacklock, and O. Tjornbo. 2016. How game changers catalyzed, disrupted, and incentivized social innovation: three historical cases of nature conservation, assimilation, and women's rights. Ecology and Society 21(4):13. http://dx.doi.org/10.5751/ES-08811-210413

Westley, F., P. Olsson, C. Folke, T. Homer-Dixon, H. Vredenburg, 
D. Loorbach, J. Thompson, M. Nilsson, E. Lambin, J. Sendzimir, B. Banerjee, V. Galaz, and S. Van Der Leeuw. 2011. Tipping towards sustainability: emerging pathways of transformation. Ambio. 40(7):762-780. http://dx.doi.org/10.1007/s13280-011-0186-9

Westley, F. R., O. Tjornbo, L. Schultz, P. Olsson, C. Folke, B. Crona, and Ö. Bodin. 2013. A theory of transformative agency in linked social-ecological systems. Ecology and Society 18(3):27. http://dx.doi.org/10.5751/es-05072-180327

Westley, F. R., B. Zimmerman, and M. Q. Patton. 2006. Getting to maybe: how the world is changed. Vintage Canada, Toronto, Ontario, Canada.

World Economic Forum. 2015. Global risks 2015. Tenth Edition. World Economic Forum, Geneva, Switzerland. 